\title{
Moral Profile of Adolescent in Kedu Region, Indonesia
}

\author{
Purwati $^{1 *}$, Arie Supriyatna ${ }^{1}$, Nofi Nur Yuhenita ${ }^{1}$ \\ ${ }^{1}$ Faculty of Teacher Training and Education, Universitas Muhammadiyah Magelang, Magelang, Indonesia \\ ${ }^{*}$ Corresponding author. Email: bupurwati@ummgl.ac.id
}

\begin{abstract}
Moral coaching as part of the formation of adolescent character becomes an important discourse today. This study aims to reveal the profile and perceptions of adolescents about morale in Kedu region. This study utilized a mixed methods design. Participants are middle school students with 100 students as subjects. Study activities included survey, school observations and in-depth interviews. Research variable that includes three aspects, namely honesty, responsibility, and social care. The results obtained: (1) 40\% responsibility, (2) 35\% honesty, (3) $25 \%$ social care. In addition to the findings of these figures, other results show that: (1) adolescents who are considered honest are adolescents who say everything according to the facts, do not exaggerate and reduce their words; they answer the question as it is; (2) responsible youth will think about their actions before acting and do their work on time, if they are faced with problems they are able to solve them, if given the task they can do it correctly, willing to take responsibility for something that has been done; (3) adolescents with social care characteristics show that they paid attention to friends and sensitive to the environment, help other people's difficulties, and want to help people who are in trouble.
\end{abstract}

Keywords: moral profile, adolescent, character

\section{INTRODUCTION}

The industrial revolution 4.0 era was followed by a very rapid development of information and technology. Conditions like this make it very easy for us to access all information and data from various aspects. This development has resulted in the transfer of information which contains various values both negative and positive that can affect the community. These values can sometimes not be filtered, so that it will easily affect the thinking of the community and have an impact on character development. The development of character that leads to the negative side will cause concern, such as the decline in identity or norms and values. In addition, it is also feared there will be a decrease in the nationalism, in nation's socio-cultural values, and in individual morality. Based on these concerns, there is a need for a model that can enhance and strengthen the moral character of individuals in society in general, and the moral character of adolescents in particular. How to build and design a moral in the formation of a strong character in the current millennial generation, not only discourse, but how to make it happen [1].

According to Lickona, character is mentioned as "A reliable inner disputation to respond to situations in a morally good way [2]." Furthermore, it was added that "Character conceived has three interrelated parts, moral knowing, moral feeling, and moral behavior". Referring to this understanding, good character must include the knowledge of goodness, then grow commitment (intention) to goodness and ultimately do good itself. That there are 4 basic pillars of the moral values of character education [3], namely: intellectual development, spiritual and emotional development, physical and kinesthetic development, and affective and creativity development.
One reason for the inability of individuals to behave well even though they already have knowledge about the good (moral knowing) is because they are not trained to do good (moral doing). Moral Knowing as the first aspect has six elements, namely moral awareness, knowing moral values, perspective taking, moral reasoning, decision making, and self-knowledge. Whereas moral loving or moral feeling is strengthening the emotional aspects of students to become a characterized human being, and the social environment [4]. Applying a character building is no longer a choice, but a necessity that must not be avoided. The previous studies [5], [6], only focused on teenage drinkers in the District of Suli. Other studies about morals reveals the moral development and attitudes of adolescents, and there are many more studies on morals but there has never been a discussion about the moral point of view of adolescents themselves, how adolescents know the word moral and how they picture moral for themselves, especially teenagers in Kedu. In this study, it will be focused on the perspective of adolescents on the moral profile and its influence on character development, therefore, there is a novelty of more comprehensive findings, equating perceptions to easily analyze and explore problems, determine the direction of policy and cooperation from internal and external parties.

\section{METHOD}

This study utilized a mixed design method in which Mixed research combines quantitative methods and qualitative research methods into a single study to answer the same research question (s). Participants are middle school students with 100 students in the Kedu Region. The subjects were obtained by random sampling which is each research area that can be represented. Study activities include surveys with Closed-ended questions come in a multitude 
of forms, including: multiple choices, drop downs, checkboxes, and ranking questions, observations with prefilled checklists and in-depth interviews. This research reveals profiles and perceptions of adolescents about morals. The instrument contains moral aspects, such as aspects of honesty, aspect of responsibility, and aspect of social care. This instrument was created to express adolescent perceptions about each of these moral aspects. In-depth interviews assessing moral aspects, aspects of honesty, aspect of responsibility, and aspect of social care. using a semi-structured interview guide.

Informed consent was obtained verbally over the telephone, and written consent was obtained prior to commencement of study activities. Participants completed the in-depth interview. The first research assistant served as the interviewer and the second served as the note taker. Note takers were also responsible for writing up field notes immediately. Interviews were audio-recorded. The master copy was subsequently coded and double-entered into an electronic spreadsheet. Descriptive statistics (means, frequencies, and standard deviations) were used to describe observed behaviors, For the in-depth interviews, audiorecordings were uploaded to a password-protected computer and backed up on a secure server. Recordings were then transcribed, verbatim, by trained research assistants using a transcription software program subsequently, the research team (independently read, memoir, and summarized major themes present in each transcript. After each transcript was independently reviewed, the research team members met to discuss identified themes and documents. Therefore, a total of six interviews were completed.

\section{RESULTS AND DISCUSSION}

The findings show the rise of various problems that occur in adolescents related to morale, there are many studies that examine and focus on adolescent immoral behavior. Moral research is conducted not only to find out the impact of immoral behavior, but also to explore the causes and alternative solutions to problems. Meanwhile according to [7], the key to prevent various deviant behaviors in adolescents is in the influence and role of family. Families should have clear moral rules and values. In addition, Cho (2014) also mentions that social ties and self-control have a very important role on adolescent behavior to cause them having a deviant behavior or not. Based on the findings of previous research and other studies on the important role of morality in adolescents, the scientific study in this research wants to further deepen the moral profile itself among adolescents, such as how they understand morals to form a character of adolescent, and how their views on morals themselves.

Deviant behavior in adolescents often manifests in the form of violations of the norms that exist in the social environment and school [8]. This study found the results of various deviant behavior, and after all data was obtained, both observations and interviews, the data were utilized a mixed design method. From these various behaviors, the aspects related to adolescent moral behavior can be obtained. The following are the results of data analysis obtained:

Table 1 The results of data analysis

\begin{tabular}{|lcc|}
\hline Aspects & $\begin{array}{c}\text { Number of } \\
\text { Subject }\end{array}$ & Percentage \\
\hline Responsibility & 40 & $40 \%$ \\
Honesty & 35 & $35 \%$ \\
Social Care & 25 & $25 \%$ \\
Total & 100 & $100 \%$ \\
\hline
\end{tabular}

A description of the results is as follows:

\subsection{Honesty Aspect}

From the overall research subjects, it was found that the figures of adolescents who were considered honest were teenagers who said what they were according to facts. Adolescents in Kedu have a score of $35 \%$ related to the level of honesty.

\subsection{Responsibility Aspects}

The subjects in this study revealed that responsible youth will think about their actions before they act and do their work on time. Teenagers who are responsible are those who can be trusted by others, because when there is a task for them to do, they will work according to their ability, and when someone is entrusting something, they will look after it with full responsibility, and if an item/object is lost, they are ready to accept the risk.

\subsection{Social Care Aspects}

Related to this aspect, the subjects in this study suggest that adolescents who have social care means that they paid close attention to their friends and is sensitive in the conditions and environment. In addition, it was mentioned that social care means being able to help friends when in trouble and is willing to help people in distress, giving up everything for people in need, and able to see the environment around them.

This is in line with what was stated that there are parties who play an important role in children's moral education, such as parents, peers, teachers and the social environment [9]. Teachers who act as role models in schools are very influential on character building. The teacher's role in the approach to students places an emphasis on helping students to assess their own feelings and actions to increase their awareness of values. In the process of education, teacher is a real example in applying the values of character taught. In the data collection conducted by researchers related to the role of parents in the formation of character, respondents provide a variety of answers. Respondents said that parents have a role to guide, teach and give examples of honesty, responsibility, and social care. Parents are the first environment, where someone learns about anything, including character. Parents can accustom their children to 
always behave honestly wherever they are, and be responsible for whatever is done, and have a sense of caring for others and the environment.

Many immoral behaviors that actually stems from violence within the family. Violence in the family environment can shape the characteristics of adolescents to be more aggressive, social problems and high crime rates. Peer circles for adolescents have a very close role in character development. At this time, teenagers will spend a lot of time with their peers. This will result in peer relationships to increase and simultaneously reduce the close relationship between teenagers and parents.

\section{CONCLUSION}

Character development is an important part of the education process, which is will be focused on re-applying positive values and morals filtering out negative values that can be affect individual behavior whereas responsible teenagers are those who do their task correctly when asked, able or willing to bear the cause or what had resulted from their actions. Adolescents who were considered honest were teenagers who said what they were according to facts. Teenagers who have social care means that they paid attention to their friends and are sensitive in conditions and environment. Future research might be able to explore how parents attempt to instill morals in shaping the character of their children, and what are the difficulties, should the moral module of character formation be given to adolescents. Therefore, it will produce more comprehensive research on all perceptions.

\section{ACKNOWLEDGMENT}

This empirical study is outputs of the Ministry of Research and Technology DRPM Grant Research funded by the Directorate of Research and Community Service with a number of grant contracts.

\section{REFERENCES}

[1] J. Nagy, J. Oláh, E. Erdei, D. Máté, and J. Popp, "The role and impact of industry 4.0 and the internet of things on the business strategy of the value chain-the case of hungary," Sustainability, vol. 10, no. 10, 2018.

[2] Marzuki, "Pengintegrasian Pendidikan Karakter Dalam Pembelajaran di Sekolah," J. Pendidik. Karakter, vol. 34, no. 1, 2012.

[3] Sartono, "Pengintegrasian Pendidikan Karakter dalam Pengembangan Kurikulum Tingkat Satuan Pendidikan.," 2011.

[4] A. Mannan, "Pembinaan Moral dalam Membentuk Karakter Remaja," J. Aqidah-Ta, vol. III, no. 1, pp. 5972, 2017.

[5] P. Y. Dewi, "Hubungan Antara Kelekatan Terhadap Orangtua Dengan Identitas Diri Pada Remaja Pria Delinquent Di Lembaga Pemasyarakatan Anak Kutoarjo," 2009.

[6] Zuldafrial, "Perkembangan Nilai, Moral Dan Sikap Remaja," Al-Hikmah, vol. 8, no. 2, pp. 29-48, 2015.

[7] M. Iqbal, "Penanggulangan Perilaku Menyimpang (Studi Kasus SMA Negeri 1 Pomalaa Kab. Kolaka Sulawesi Tenggara)," Lentera Pendidik. J. Ilmu Tarb. dan Kegur., vol. 17, no. 2, pp. 229-242, 2014.

[8] F. Nabiswa Makhanu, C. Author, J. Nabiswa, B. L. Misigo, and F. N. Makhanu, "Analysis of student deviant behaviour most prevalent in schools of Bungoma County," Quest Journals J. Res. Humanit. Soc. Sci., vol. 4, no. 11, pp. 2321-9467, 2016.

[9] J. Subianto, "Peran Keluarga, Sekolah, Dan Masyarakat Dalam Pembentukan Karakter Berkualitas," Edukasia J. Penelit. Pendidik. Islam, vol. 8, no. 2, pp. 331-354, 2013. 